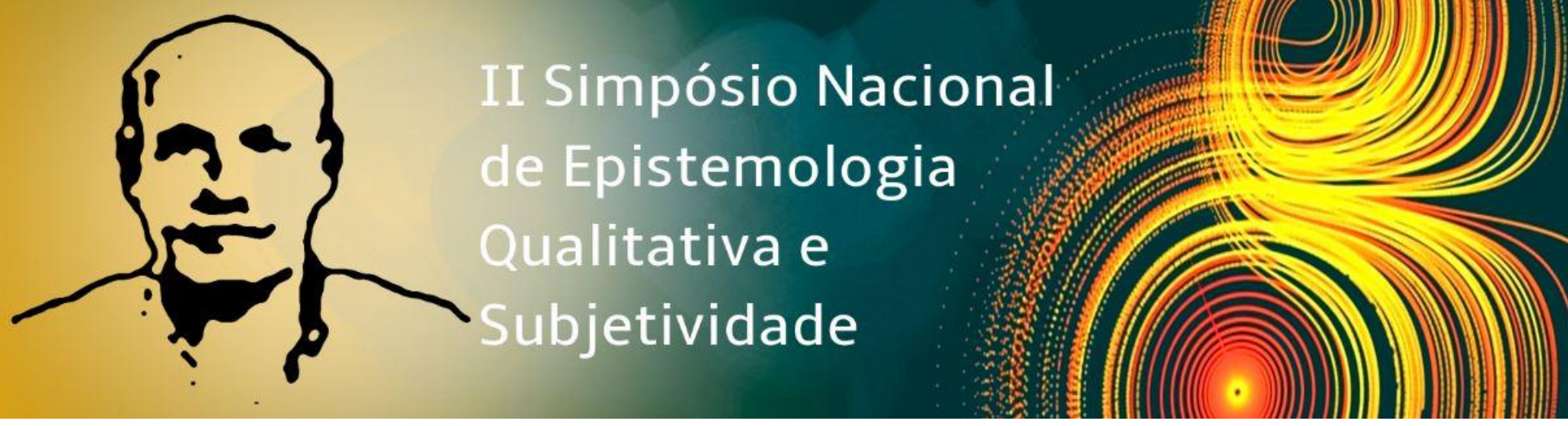

Eixo temático: 5. Aprendizagem e dificuldades de aprendizagem na perspectiva da subjetividade

\title{
O PROFESSOR CRIATIVO E A APRENDIZAGEM CRIATIVA DE SEUS ALUNOS: UM ESTUDO DE CASO NA ESCOLA DE APLICAÇÃO DA UNIVERSIDADE FEDERAL DO PARÁ (EA/UFPA)
}

LIMA, Gabrielle Gomes de, UFPA, gabriellegomesdelima@gmail.com ALVES, José Moysés, UFPA, jmalves@ufpa.br

\section{Resumo}

A criatividade pode manifestar-se no ensino e aprendizagem. Mas professores criativos não tem, necessariamente, alunos criativos e o contrário também é verdadeiro. Criar é produzir algo novo e valioso. O professor criativo produz práticas pedagógicas diferenciadas que resultam em aprendizagem e desenvolvimento dos alunos (MITJÁNS MARTÍNEZ, 2006). Os tipos de aprendizagem que fazem avançar o desenvolvimento são aquelas em que emerge o sujeito que aprende (GONZÁLEZ REY, 2006) e ele produz sentidos subjetivos sobre o aprendido, isto é, relaciona os conhecimentos novos com sua história pessoal, suas configurações de processos simbólicos e emocionais. O sujeito que aprende não emerge na aprendizagem memorísticoreprodutiva, mas comparece nas aprendizagens compreensiva, na qual empenha seus recursos reflexivos e na aprendizagem criativa, quando investe sua imaginação criadora para personalizar a informação, problematiza-la e transcende-la (MITJÁNS MARTÍNEZ; GONZÁLEZ REY, 2017). Neste sentido, em nossa pesquisa objetivamos realizar um estudo de caso com uma turma de Ciências de um professor criativo, para investigar como se relacionam a criatividade pedagógica do professor com a aprendizagem criativa de seus alunos. Neste resumo, apresentamos um esboço do modelo teórico inicial. Assumindo que não existe uma relação direta entre as ações criativas do professor e a aprendizagem criativa dos alunos, mas que o professor criativo pode favorecer tais aprendizagens, refletimos sobre algumas possibilidades de isto acontecer. Primeiro, porque o professor criativo é um modelo de aprendiz 


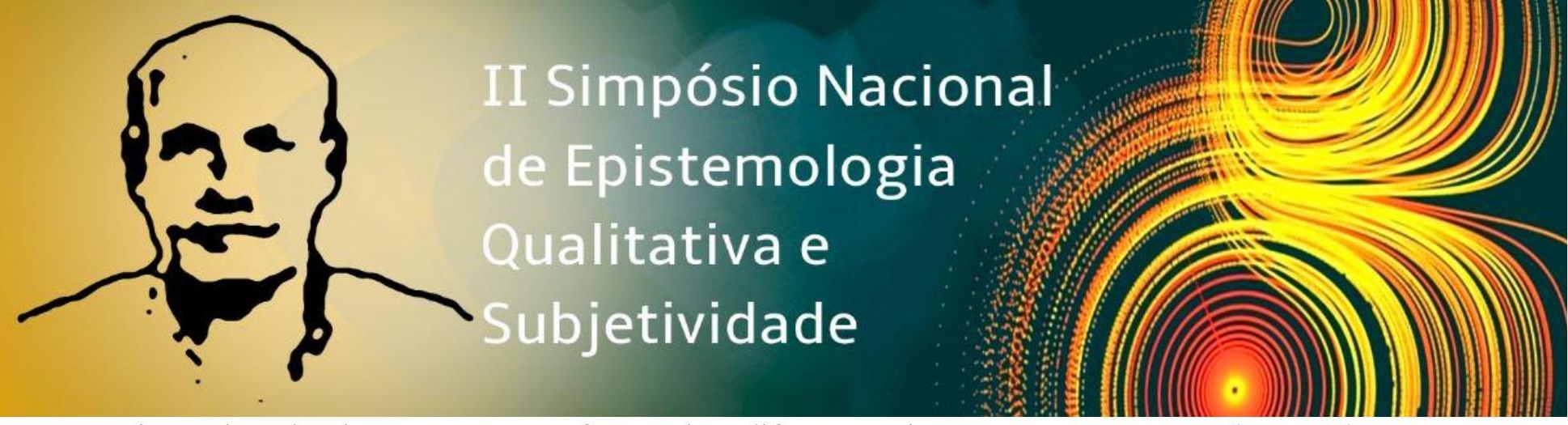

curioso e imaginativo, que costuma fazer coisas diferentes e interessantes para seus alunos. Ele costuma personalizar as informações, problematizas-las e criar ideias novas com elas. Ele também pode estimular a curiosidade e a imaginação de seus alunos e demandar que eles personalizem, problematizem e façam coisas diferentes com as informações disponíveis. Porém, em sala de aula, nem tudo acontece a partir da iniciativa do professor. Neste sentido, objetivamos investigar como as configurações subjetivas sociais, que emergem na sala de aula a partir da iniciativa do professor ou dos estudantes, favorecem a produção individual de sentidos subjetivos envolvidos na aprendizagem criativa de estudantes de biologia. Realizaremos a pesquisa em uma turma de um professor criativo na EA/UFPA. Observaremos a turma durante um semestre e utilizaremos instrumentos como complementos de frases, redações, conversas individuais e grupais com os participantes da pesquisa. Realizaremos uma pesquisa qualitativa, conforme os princípios da Epistemologia Qualitativa (GONZÁLEZ REY; MITJÁNS MARTÍNEZ, 2017). Para o debate, formulamos a pergunta: Como o professor criativo pode favorecer a aprendizagem criativa dos alunos e como investigar tal processo?

Palavras chave: Criatividade; Subjetividade; Ensino e aprendizagem de biologia.

\section{Referências}

GONZÁLEZ REY, F.L. O sujeito que aprende: desafíos do desenvolvimento do tema da aprendizagem na psicología e na prática pedagógica. In: TACCA, M.C.V.R. (Org). Aprendizagem e Trabalho pedagógico. Campinas: Alínea, 2006.

\section{; MITJÁNS MARTINEZ, A. Subjetividade: teoria,} epistemologia e método. Campinas: Alínea, 2017.

MITJÁNS MARTÍNEZ, A. Criatividade no trabalho pedagógico e criatividade na aprendizagem: uma relação necessária? In: TACCA, M.C.V.R. (Org). Aprendizagem e Trabalho pedagógico. Campinas: Alínea, 2006.

; GONZÁLEZ REY, F.L. Psicologia, educação e aprendizagem escolar: avançando na contribuição da leitura cultural-histórica. São Paulo: Cortez. 2017. 